\title{
CHARACTERIZATION OF LAMB BURGERS WITH ADDITION OF FLOUR FROM PEACH PALM BY-PRODUCT
}

\author{
CARACTERIZAÇÃO DE HAMBÚRGUERES DE CORDEIRO COM ADIÇÃO DE \\ FARINHA DE SUBPRODUTO DE PUPUNHA
}

\author{
Larissa ECHEVERRIA ${ }^{1}$; Jéssica da Mata RIGOTO ${ }^{2}$; Antônio Campanha MARTINEZ ${ }^{3}$; \\ Barbara Daniele Almeida PORCIUNCULA²; Juliana SCANAVACCA ${ }^{2}$; \\ Beatriz Cervejeira Bolanho BARROS ${ }^{2 *}$ \\ 1. Department of Technology, Graduate Program in Sustainability, State University of Maringá, Umuarama, PR, Brazil; 2. Department \\ of Technology, State University of Maringá, Umuarama, PR, Brazil; 3. Department of Veterinary Medicine, State University of \\ Maringá, Umuarama, PR, Brazil. *bcbolanho2@uem.br
}

\begin{abstract}
There is an increased interest in the consumption of healthier and innovative meat products. This study aimed to produce lamb burgers by replacing pork fat by peach palm by-product flour PPF. The burgers were produced with lambs that had a safflower seed-supplemented diet. The PPF was added at levels of $0 \%(\mathrm{H} 0), 3 \%(\mathrm{H} 3), 6 \%(\mathrm{H} 6)$ and $9 \%(\mathrm{H} 9)$ in the substitution of fat. The flour produced with peach palm by-product showed high fiber content $(63.9 \%)$ and high capacity of water absorption $\left(8.1 \mathrm{~g} \cdot \mathrm{g}^{-1}\right)$ and oil absorption $\left(3.8{\mathrm{~g} . \mathrm{g}^{-1}}^{-1}\right.$. The PPF addition increased the cooking yield $(68.2-77.0 \%)$, moisture retention $(38.5$ $43.4 \%)$ and dietary fiber content $(3.2-7.0 \%)$ in relation to H0, while the color parameters were similar among the formulations. The sensorial attributes overall appearance and aroma did not differ $(p>0.05)$ in the lamb burgers produced, but the highest scores for flavor, texture and purchase intention were observed for $\mathrm{H} 0, \mathrm{H} 3$ and H6. PPF addition to lamb burgers increased the hardness values, and it did not affect elasticity and cohesiveness. The microbiological parameters showed that the formulations are safe for consumption. Therefore, PPF can be considered a low-cost alternative to nutritional enrichment of lamb burgers, being the level of $6 \%$ the most recommended due to the sensorial acceptance.
\end{abstract}

KEYWORDS: Bactris gasipaes. Dietary fiber. Meat patties.

\section{INTRODUCTION}

The production of lamb meat has been increasing throughout the world, with a head population of 1.2 billion and the meat production amounted to 8.9 million tons in the least years (FAO, 2016). It is expected an increase in lamb meat production, especially because of its composition, like beneficial fatty acids (FAs), whose consumption can be associated with benefits to human health (CHIKWANHA et al., 2018).

There are several health disorders, like cardiovascular disease, diabetes, cancer and obesity that are directly associated with the human diet. A preventive health care strategy can be achieved with the consumption of functional foods products, with nutritional enrichment, such as the addition of fibers, antioxidants, prebiotics, and others. However, in the development of this kind of product, there are important factors that can impact consumer decisions, such as taste, convenience and price (DECKER; PARK, 2010).

Meat has high nutritional value due to the high protein content and the presence of vitamins and minerals like iron and zinc (BOADA;
HENRÍQUEZ-HERNÁNDEZ; LUZARDO, 2016), which can be influenced by the fed diet (COBELLIS et al., 2015; ABREU et al., 2019). The animal fed diet can also be studied to proportionate sensorial benefits to meat products, enhancing the aroma, texture, flavor and overall acceptability (CHIKWANHA et al., 2018; WATKINS et al., 2014). A previous study verified that lambs fed with a supplemented diet containing $15 \%$ of safflower (Carthamus tinctorius L.) seeds have positive effects on sensory properties of the burgers produced, which also had lower lipid and caloric content when compared with beef burgers (OLIVEIRA et al., 2021).

Another promising trend to improve the quality and the nutritional value of meat products is the use of vegetable fibers in the replacement of fat. It can be due to the physicochemical properties of fibers, such as improving texture, enhancing water holding capacity, stabilizing fat in emulsified products, thus, they can exhibit a fat mimetic behavior in reduced-fat products (PETRACCI et al., 2013).

The agro-industrial by-products are an alternative to obtain fibers at a low cost. The 
cultivation of peach palm (Bactris gasipaes Kunth) to obtain palm heart has grown in Brazil, because of its desirable characteristics when compared to those of predatory exploitation and advantages such as rapid growth, early maturity for cutting (2 years) and growth of stems from offshoots. However, the peach palm processing generates a large volume of residue, around $83 \%$ of the stem weight (BOLANHO; DANESI; BELÉIA, 2013). The byproducts can be used to flour production, which had high fiber content (62\%) (BOLANHO; DANESI; BELÉIA, 2014).

The fibers from by-products can be employed as fat substitutes in meat products, for example, in hamburgers formulations, improving its nutritional value. This class of product exhibits industrial and economic importance (ANGOR; ALABDULLAH, 2010), and its quality and nutritional value depend on meat type, ingredients used in the formulation, processing conditions, and others (GUEDES-OLIVEIRA et al., 2016). This study aimed to develop and characterize lamb burgers with the replacement of different levels of fat by peach palm by-product flour.

\section{MATERIAL AND METHODS}

\section{Material}

The lambs used in the study came from the Animal Breeding Laboratory of Maringa State University, located in the experimental farm (Umuarama/PR). The lambs had an average age of 5 years, a mean body score of 1.5 , which were housed in covered bays. Feeding was given, according to Table 1, at 3 times $(8 \mathrm{~h}$ and $12 \mathrm{~h}$ a.m., $4 \mathrm{~h} \mathrm{p.m.)}$ in the proportion of $3.5 \%$ of dry matter in relation to the animal body weight, following the recommendations of the National Health and Medical Research Council - NCR (2007). A previous study showed that the addition of $15 \%$ of safflower seed had a positive effect in the sensorial acceptance and the chemical composition of lamb meat, so it was added to the fed diet (OLIVEIRA et al., 2021). After 60 days of this feeding, the lambs were slaughtered using the protocol of animal welfare and with the official municipal inspection. The carcasses were cooled to $4^{\circ} \mathrm{C}$ for $24 \mathrm{~h}$ and then boned and frozen.

The ingredients used in the lamb burgers formulations were from local market of Umuarama/PR. The reagents used in the analysis of proximal composition were of analytical grade.

Table 1. Ingredients and chemical composition of lamb's diet in the confinement period

\begin{tabular}{lc|lc}
\hline \multicolumn{1}{c|}{ Ingredients used in the fed diet (\%DM) } & \multicolumn{2}{c}{ Chemical composition (\%DM) } \\
\hline Safflower seed & 15.00 & Dry matter & 84.51 \\
Corn grain & 49.63 & Crude protein & 15.18 \\
Soybean meal & 10.37 & Ether extract & 5.47 \\
Hay Tiffton 85 & 20.00 & Neutral detergent fiber & 33.45 \\
Mineral $^{1}$ & 5.00 & Acid detergent fiber & 16.33 \\
& & Mineral matter & 3.67 \\
\hline
\end{tabular}

DM - Dry massis

\section{Production of flour from peach palm by-product}

The flour used in this study was produced from unused part of the stem of peach palm, harvested in Mariluz (Paraná, Brazil). The stem portion was separated and subjected to washing, cutting and drying in an oven with forced air circulation (MA 035, Marconi, Piracicaba, Brazil) at $60{ }^{\circ} \mathrm{C}$ for $36 \mathrm{~h}$. The dried material was ground in a knife mill (type Willye SL-031; Solab, Piracicaba, Brazil) and sifted in a set of sieves. The flour classified in the sieve of particle size of $150 \mu \mathrm{m}$ was used in the study.

\section{Lamb burgers production}

The normative instruction $\mathrm{n}^{\circ} \quad 20$, $31 / 07 / 2000$, of Ministry of Agriculture Livestock and Food Supply - MAPA (BRAZIL, 2000) was followed to the lamb burgers production. The lamb meat was cut at $0^{\circ} \mathrm{C}$, ground into an $8 \mathrm{~mm}$ disc and mixed to different proportions of flour from peach palm by-product (PPF) and pork fat. The control had $0 \%$ of PPF and $9 \%$ of pork fat $(\mathrm{H} 0)$, the formulations $\mathrm{H} 3, \mathrm{H} 6$ and $\mathrm{H} 9$ had, respectively, 3\% of PPF and $6 \%$ of pork fat, $6 \%$ of PPF and $3 \%$ of pork fat, $9 \%$ of PPF and $0 \%$ of pork fat. The other ingredients were added and mixed in the sequence: textured soy protein $(3.45 \%)$, ice water $(6.00 \%)$, salt $(1.02 \%)$, ground white pepper $(0.07 \%)$, garlic powder $(0.08 \%)$, monosodium glutamate $(0.31 \%)$ and dried chives $(0.07 \%)$. The lamb meat corresponds to $80 \%$ of each formulation. The lamb burgers were molded with approximately $80 \mathrm{~g}$, packaged and frozen at $-14^{\circ} \mathrm{C}$ until the moment of the analyzes. 


\section{Physicochemical analysis}

The flour obtained from the stem part from peach palm was characterized as water absorption index (WAI), using $2 \mathrm{~g}$ of sample and $20 \mathrm{~mL}$ of water. The mixture was stirred in a shaker (Marconi, MA35) at $100 \mathrm{rpm}, 30 \mathrm{~min}$ and after it was centrifuged at $3000 \mathrm{~g}$ for $10 \mathrm{~min}$. The residue of centrifugation was weighed and this value was divided by the weight of dry matter to obtain WAI. The result was expressed in $g$ of water absorbed $\mathrm{g}^{-1}$. At same way, the oil absorption index was determined, but replacing water by commercial soybean oil (AZIZ et al., 2011).

The chemical composition of PPF and lamb burgers formulations were determined by AOAC methods: dietary fibers (method 991.43), moisture (method 925.09), proteins (method 920.87), ashes (method 923.03) and lipids (method 920.85) (HORWITZ; LATIMER, 2005).

To determine the cooking characteristics of the lamb burgers, the weight and diameter of the formulations were verified before and after frying. The lamb burgers were fried in skillet, greased with vegetable oil for about $8 \mathrm{~min}$. The cooking yield and moisture retention were calculated by equations 01 and 02 (SEABRA; ZAPATA; NOGUEIRA, 2002).

$$
\% \text { cooking yield }=\frac{\text { cooked sample }}{\text { crude sample }}
$$

$\%$ moisture retention $=\frac{\% \text { yield } x \% \text { sample moisture }}{100}$

The color characteristics of the sample, before and after frying, were determined using the colorimeter Color Reader CR-10, Konica Minolta, in relation to the CIE-Lab parameters: $\mathrm{L}^{*}$ (lightness), $+\mathrm{a}^{*}$ (red) $-\mathrm{a}^{*}$ (green), and $+\mathrm{b}^{*}$ (yellow) $-b^{*}$ (blue).

\section{Microbiological analysis}

In the formulations produced were determined the microbiological parameters required by Brazilian legislation (BRASIL, 2001), Coliforms at $45{ }^{\circ} \mathrm{C}$, Staphylococcus coagulase positive and Salmonella spp., following the methods of American Public Health Association - APHA (2001). These analyses were realized as pre requisite to sensory evaluation.

\section{Textural and sensory analysis}

To determine texture profile it was used a TA-XT2i texturometer (TA-XT2i, Extralab, São
Paulo) equipped with a $70-\mathrm{mm}$ diameter probe, at $0.3 \mathrm{~mm} . \mathrm{s}^{-1}$ (POLIZER et al., 2015). The curves of force versus time generated by the equipment were used to determine springiness $(\mathrm{S})$, hardness $(\mathrm{H})$, chewiness $(\mathrm{Ch})$, gumminess $(\mathrm{G})$ and cohesiveness (Co).

The sensory acceptance analysis of the lamb burgers formulations was applied to an untrained testers panel $(n=100)$ of both sexes and ages from 16 to 60 years, after the approval of Ethics Committee - COPEP-UEM/CAAE: 66525917.8.0000.0104. It was used a structured nine-point hedonic scale, $(9=$ like extremely; $8=$ like very much; $7=$ like moderately; $6=$ like slightly; $5=$ neither like nor dislike; $4=$ dislike slightly; 3 = dislike moderately; 2 = dislike very much; 1 = dislike extremely). For purchase intention, a structured five-point scale was used, ranging from 1 , which corresponds to "would not buy", up to 5, which corresponds to "certainly buy". The burgers formulations were grilled on a grill for about 8 minutes using $1 \mathrm{~mL}$ of vegetable oil. The samples $(20 \mathrm{~g})$ were provided in disposable cups encoded and randomized (DUTCOSKY, 2013).

\section{Statistical analysis}

All the assays were performed in triplicate for PPF and formulations. The results were subjected to variance analysis (ANOVA) and Tukey test at a 5\% significance level with software Statistica ${ }^{\circledR} 8.0$.

\section{RESULTS AND DISCUSSION}

\section{Composition and technological properties of peach palm by-product flour}

The flour produced with the stem part of peach palm (PPF) had similar values of composition and technological properties (Table 2) than that found by BOLANHO; DANESI; BELÉIA (2014). It can be observed that the dietary fiber is the main flour component $(63.90 \%)$, which is important due to its functional properties that can promote the consistency, texture, rheological behavior and sensory characteristics of food products. Moreover, the by-products rich in fibers can be used for economic and technological purposes, as a bulking agent, or fat substitute (ELLEUCH et al., 2011). Industries are finding that incorporating fiber into their products is a good way to make them healthier and subsequently more appealing to healthconscious consumers (PSZCZOLA, 2008). 
Table 2. Chemical composition and technological properties of flour obtained from peach palm by-product

\begin{tabular}{lc}
\hline Component/Properties & \\
\hline Moisture (\%) & $6.34 \pm 0.19$ \\
Ash (\%) & $4.89 \pm 0.11$ \\
Protein (\%) & $9.15 \pm 0.10$ \\
Crude fat (\%) & $2.11 \pm 0.05$ \\
Total dietary fiber (\%) & $63.90 \pm 3.55$ \\
Water absorption (g of absorbed water.g $^{-1}$ ) & $8.10 \pm 0.18$ \\
Oil absorption (g of absorbed oil.g $^{-1}$ ) & $3.77 \pm 0.15$ \\
\hline
\end{tabular}

Mean values \pm standard error, $\mathrm{n}=3$

Water and oil absorption of PPF was higher than the values found by the by-product's flours of Buriti fruit (RESENDE; FRANCA; OLIVEIRA, 2019), pequi fruit (LEÃO et al., 2017) and defatted rice bran (WANG et al., 2016). The water absorption index is related to the ability of a substance to link water under specific conditions, influencing the functional and sensory properties of food products (SREERAMA et al., 2012). In meat products, this property can also help to avoid weight loss during cooking (POLIZER et al., 2015). The oil absorption is also an important property of flours, retaining the flavor and aroma compounds and it can be used in various types of applications, like emulsion-type meat products (JITNGARMKUSOL; HONGSUWANKUL; TANANUWONG, 2008).

\section{Physicochemical properties of lamb burgers}

In relation to cooking properties (Table 3), the formulations produced with PPF addition (H3, H6, H9) did not show significative differences $(p>0.05)$ in the parameter's moisture retention and cooking yield. The inclusion of $6 \%$ or $9 \%$ of PPF in the production of lamb burgers increased the cooking yield in relation to the control formulation $(\mathrm{H} 0, \mathrm{p}<0.05)$. It can be related to the high-water holding capacity of peach palm by-product flour (Table 2), that could retain the water released from the meat during thermal processing (BAUGREET et al., 2016). Quantities equal or higher than 3\% of PPF increased moisture retention when compared to $\mathrm{HO}$ formulation. This find is in accordance with López-López et al. (2010) that observed that the fiber addition to beef burgers improved the moisture retention, due to the water holding capacity of the fiber components.

Table 3. Cooking properties and $\mathrm{pH}$ of lamb burgers produced with different proportions of peach palm byproduct flour and pork fat

\begin{tabular}{|c|c|c|c|c|}
\hline Variable & Ho & H3 & H6 & H9 \\
\hline Cooking yield (\%) & $60.74 \pm 5.47^{b}$ & $68.24 \pm 5.08^{\mathrm{ab}}$ & $75.52 \pm 6.73^{\mathrm{a}}$ & $77.01 \pm 6.35^{\mathrm{a}}$ \\
\hline Moisture retention (\%) & $31.27 \pm 2.82^{\mathrm{b}}$ & $38.54 \pm 3.44^{\mathrm{a}}$ & $43.05 \pm 3.98^{\mathrm{a}}$ & $43.42 \pm 3.15^{\mathrm{a}}$ \\
\hline pH & $6.10 \pm 0.02^{b}$ & $6.04 \pm 0.03^{\mathrm{a}}$ & $6.02 \pm 0.00^{\mathrm{a}}$ & $6.02 \pm 0.00^{\mathrm{a}}$ \\
\hline Color parameters & \multicolumn{4}{|c|}{ Before cooking } \\
\hline $\mathbf{a}$ & $10.84 \pm 0.75^{\mathrm{a}}$ & $9.78 \pm 0.81^{\mathrm{a}}$ & $10.60 \pm 0.09^{\mathrm{a}}$ & $7.91 \pm 1.18^{\mathrm{a}}$ \\
\hline b & $12.51 \pm 0.52^{\mathrm{a}}$ & $14.63 \pm 0.68^{\mathrm{a}}$ & $14.71 \pm 1.43^{\mathrm{a}}$ & $15.22 \pm 1.25^{\mathrm{a}}$ \\
\hline $\mathbf{L}^{*}$ & $45.00 \pm 0.04^{\mathrm{a}}$ & $49.36 \pm 1.02^{\mathrm{a}}$ & $50.08 \pm 1.66^{\mathrm{ab}}$ & $56.90 \pm 1.49^{\mathrm{b}}$ \\
\hline Color parameters & \multicolumn{4}{|c|}{ After cooking } \\
\hline $\mathbf{a}$ & $7.19 \pm 0.28^{\mathrm{a}}$ & $9.74 \pm 1.02^{\mathrm{a}}$ & $9.01 \pm 0.20^{\mathrm{a}}$ & $10.27 \pm 0.96^{\mathrm{a}}$ \\
\hline b & $17.05 \pm 0.10^{\mathrm{a}}$ & $22.26 \pm 1.80^{\mathrm{ab}}$ & $22.46 \pm 1.42^{\mathrm{ab}}$ & $27.05 \pm 0.20^{b}$ \\
\hline $\mathbf{L}^{*}$ & $38.25 \pm 0.70^{\mathrm{a}}$ & $40.19 \pm 0.00^{\mathrm{a}}$ & $40.32 \pm 0.17^{\mathrm{a}}$ & $41.46 \pm 1.56^{\mathrm{a}}$ \\
\hline
\end{tabular}

Velioglu et al. (2010) found similar values of moisture retention $-29.98 \%$ to $43.13 \%$ - in beef burgers formulations. According to these authors, the higher values of moisture retention are important since during their cooking, meat proteins denature causing a decrease in water holding capacity and shrinkage of the network proteins. This shrinkage exerts a mechanical force between the water and the fibers. In the presence of these pressure gradients, the excess of water is expelled to the surface of the meat. To avoid this effect, it is generally recommended the addition of textured soy protein, 
Characterization of lamb...

which content was maintained equal in the formulations developed in this work.

The addition of PPF decreased the $\mathrm{pH}$ values of lamb burgers formulations $(p<0.05)$, (Table 3) in relation to $\mathrm{H} 0$, however, among the $\mathrm{H} 3$, H6 and H9 samples, such difference was not observed $(p>0.05)$. Similar results were observed by Kim et al. (2016) in beef burgers added of hull pectin and insoluble fiber. The values found in this work are considered acceptable for consumption (5.80 to 6.30) for processed meat products (FLOREK et al., 2004).

Color, appearance and presentation of the product are very important for the consumer and greatly influence purchasing decisions (NASSU et al., 2012). The development of functional meat products with color characteristics similar to their conventional alternative is desirable (BAUGREET et al., 2016). The redness ( $\left.\mathrm{a}^{*}\right)$ was similar among the formulations before and after cooking $(\mathrm{p}<0.05)$ (Table 3), which is an interesting result since the
ECHEVERRIA, L. et al.

consumers prefer bright red beef than purple or brown (BAUGREET et al., 2016). Yellowness (b*) was only affected by the addition of $9 \%$ of PPF (H9) in the cooked burgers, which can be explained by the color characteristics of the flour used $\left(a^{*}-3.4\right.$, $b^{*} 21.3$ ). The raw lamb burger $\mathrm{H} 9$ also had higher luminosity $\left(\mathrm{L}^{*}\right)$ value than the other formulations, which was not observed after cooking. It can be inferred that the occurrence of browning reactions in the cooking process minimized the alterations in $\mathrm{L}^{*}$ values observed in the raw samples.

The results for physicochemical composition (Table 4) showed that all formulations produced had similar values of moisture and ashes, except for formulation $\mathrm{H} 9$, which had the lowest moisture value, probably due to the highest content of PPF. Guedes-Oliveira et al. (2016) found similar ashes content $(3.09-3.19 \%)$ and higher values of moisture $(65.34-65.68 \%)$ than those reported in this work.

Table 4. Proximal composition of lamb burgers produced with different proportions of peach palm by-product flour and pork fat

\begin{tabular}{lcccc}
\hline Components & H0 & H3 & H6 & H9 \\
\hline Moisture (\%) & $56.48 \pm 1.20^{\mathrm{a}}$ & $57.01 \pm 2.48^{\mathrm{a}}$ & $56.39 \pm 1.14^{\mathrm{a}}$ & $54.49 \pm 0.53^{\mathrm{b}}$ \\
Ashes (\%) & $3.37 \pm 0.24^{\mathrm{a}}$ & $3.35 \pm 0.13^{\mathrm{a}}$ & $3.32 \pm 0.03^{\mathrm{a}}$ & $3.22 \pm 0.18^{\mathrm{a}}$ \\
Proteins (\%) & $25.12 \pm 1.04^{\mathrm{a}}$ & $23.81 \pm 0.80^{\mathrm{ab}}$ & $22.90 \pm 0.61^{\mathrm{b}}$ & $21.05 \pm 0.49^{\mathrm{b}}$ \\
Lipids (\%) & $13.47 \pm 0.45^{\mathrm{a}}$ & $12.75 \pm 0.47^{\mathrm{ab}}$ & $11.23 \pm 0.94^{\mathrm{bc}}$ & $11.03 \pm 0.66^{\mathrm{c}}$ \\
Dietary fiber (\%) & $1.42 \pm 0.52^{\mathrm{c}}$ & $3.22 \pm 0.50^{\mathrm{b}}$ & $5.08 \pm 0.20^{\mathrm{a}}$ & $6.98 \pm 0.24^{\mathrm{a}}$ \\
\hline
\end{tabular}

$\mathrm{H} 0$ - lamb burgers with $0 \%$ of peach palm by-product flour and $9 \%$ of pork fat; H3 - lamb burgers with 3\% of peach palm by-product flour and $6 \%$ of pork fat; $\mathrm{H} 6$ - lamb burgers with $6 \%$ of peach palm by-product flour and $3 \%$ of pork fat; $\mathrm{H} 9$ - lamb burgers with $9 \%$ of peach palm by-product flour and $0 \%$ of pork fat. Means values $( \pm$ standard error, $n=3$ ) followed by same letters (same line) did not differ statistically $(\mathrm{p}<0.05)$ by Tukey test.

The protein content decreased with the addition of 6 and 9\% of PPF (formulations H6 and H9) when compared with the H0 and $\mathrm{H} 3$ samples. The lipid content was higher $(\mathrm{p}<0.05)$ in $\mathrm{H} 0$ than the values found in the formulations containing PPF. This result is interesting due to the consumers' demand for products with lower lipid content that consequently have lower energetic value. Piñero et al. (2008) also reported a decrease in fat content when oat's soluble fiber was added to beef burgers.

The dietary fiber content increased with the PPF addition, being the highest value observed in the H9 formulation. Concerning the control formulation, there was an increase of 2 to 5 times on the dietary fiber (DF) content. According to the Brazilian legislation, a food product can be considered as a source of dietary fiber or high-fiber content, if it has at least $2.5 \mathrm{~g}$ or $5.0 \mathrm{~g}$ of DF, respectively, per portion (BRAZIL, 2012). Considering a portion of $80 \mathrm{~g}$ (1 lamb burger) the formulations $\mathrm{H} 3$ and $\mathrm{H} 6$ can be classified as a source of DF and H9 can be considered a source of high DF content. Barros et al. (2018) found 5.2 g. $100 \mathrm{~g}^{-1}$ of fibers in chicken nuggets produced with $20 \%$ of chia flour by replacing chicken skin, a value lower than those found in this work in H3, H6 and H9 formulations. Dietary fiber plays an important role in many physiological processes and it can help in the prevention of many diseases, so it has potential application as a functional ingredient with health-promoting attributes (LU; LIU; LI, 2013).

\section{Microbiological parameters of lamb burgers}

The results of microbiological analysis (Table 5) showed that all formulations were within the limits preconized by Brazilian legislation (BRASIL, 2001). The hygienic-sanitary conditions of raw materials and processing steps contributed to the achievement of safe microbial parameters for the consumption of the products formulated, which is important from the point of view of the industry and, in particular, elderly vulnerable consumers 
(BAUGREET et al., 2016). In this work these results also allowed the formulations to be analyzed as sensorial parameters.

Table 5. Microbiological parameters of lamb burgers formulations

\begin{tabular}{|c|c|c|c|c|}
\hline Variables & Ho & H3 & H6 & H9 \\
\hline Coliforms at $45^{\circ} \mathrm{C}$ (MPN.g $\left.{ }^{-1}\right)$ & $1.10 \times 10^{1}$ & $1.40 \times 10^{1}$ & $1.50 \times 10^{1}$ & $2.00 \times 10^{1}$ \\
\hline Staphylococcus coagulase positive (CFU.g $\left.{ }^{-1}\right)$ & $1.00 \times 10^{2}$ & $1.40 \times 10^{1}$ & $2.00 \times 10^{1}$ & $1.45 \times 10^{1}$ \\
\hline Salmonella spp. (in 25g) & Absence & Absence & Absence & Absence \\
\hline
\end{tabular}

MPN - most probable number; CFU - colony forming unit; $\mathrm{H} 0$ - lamb burgers with $0 \%$ of peach palm by-product flour and $9 \%$ of pork fat; $\mathrm{H} 3$ - lamb burgers with $3 \%$ of peach palm by-product flour and $6 \%$ of pork fat; H6 - lamb burgers with $6 \%$ of peach palm byproduct flour and $3 \%$ of pork fat; H9 - lamb burgers with $9 \%$ of peach palm by-product flour and $0 \%$ of pork fat. Means values, $n=3$.

\section{Texture profile and sensory of lamb burgers}

The results of texture profile analysis (TPA), Table 6, showed that the control formulation (H0) had the lowest hardness value $(p<0.05)$, without significant differences for the values found in $\mathrm{H} 3, \mathrm{H} 6$ and $\mathrm{H} 9$. This fact may be correlated with the lower fiber content of the product (Table 4)
(HAUTRIVE et al., 2008). Trevisan et al. (2016) studying the addition of oat fiber ( 3 and $6 \%$ ) in hamburgers also found that the hardness values increased with fiber addition. According to Huang et al. (2011) hardness is one of the most important parameters of meat product texture, influencing consumer preference.

Table 6. Texture profile and sensorial attributes of lamb burgers produced with different proportions of peach palm by-product flour and pork fat

\begin{tabular}{lcccc}
\hline Variables & H0 & H3 & H6 & H9 \\
\hline Hardness & \multicolumn{4}{c}{ Texture profile } \\
Elasticity & $6.93 \pm 0.21^{\mathrm{b}}$ & $10.97 \pm 1.05^{\mathrm{a}}$ & $10.13 \pm 0.85^{\mathrm{a}}$ & $11.97 \pm 0.98^{\mathrm{a}}$ \\
Cohesiveness & $3.35 \pm 0.40^{\mathrm{a}}$ & $3.46 \pm 0.39^{\mathrm{a}}$ & $3.24 \pm 0.22^{\mathrm{a}}$ & $3.68 \pm 0.09^{\mathrm{a}}$ \\
Gumminess & $0.66 \pm 0.02^{\mathrm{a}}$ & $0.64 \pm 0.02^{\mathrm{a}}$ & $0.66 \pm 0.05^{\mathrm{a}}$ & $0.68 \pm 0.01^{\mathrm{a}}$ \\
& $17.24 \pm 1.62^{\mathrm{b}}$ & $16.98 \pm 1.41^{\mathrm{b}}$ & $16.99 \pm 0.36^{\mathrm{b}}$ & $26.19 \pm 2.56^{\mathrm{a}}$ \\
\hline \multicolumn{5}{c}{ Sensorial attributes } \\
Overall appearance & $6.71 \pm 1.50^{\mathrm{a}}$ & $6.96 \pm 1.37^{\mathrm{a}}$ & $6.66 \pm 1.41^{\mathrm{a}}$ & $6.16 \pm 1.72^{\mathrm{a}}$ \\
Froma & $7.07 \pm 1.37^{\mathrm{a}}$ & $7.16 \pm 1.31^{\mathrm{a}}$ & $6.62 \pm 1.36^{\mathrm{a}}$ & $6.53 \pm 1.65^{\mathrm{a}}$ \\
Texture & $7.02 \pm 1.80^{\mathrm{a}}$ & $7.06 \pm 1.32^{\mathrm{a}}$ & $6.47 \pm 1.73^{\mathrm{ab}}$ & $5.62 \pm 1.91^{\mathrm{b}}$ \\
Purchase intention & $6.70 \pm 1.65^{\mathrm{a}}$ & $6.82 \pm 1.56^{\mathrm{a}}$ & $6.40 \pm 1.89^{\mathrm{a}}$ & $5.58 \pm 1.15^{\mathrm{b}}$ \\
\hline
\end{tabular}

$\mathrm{H} 0$ - lamb burgers with $0 \%$ of peach palm by-product flour and $9 \%$ of pork fat; $\mathrm{H} 3$ - lamb burgers with $3 \%$ of peach palm by-product flour and $6 \%$ of pork fat; $\mathrm{H} 6$ - lamb burgers with $6 \%$ of peach palm by-product flour and $3 \%$ of pork fat; $\mathrm{H} 9$ - lamb burgers with $9 \%$ of peach palm by-product flour and $0 \%$ of pork fat. Means values $( \pm$ standard error, $n=3$ ) followed by same letters (same line) did not differ statistically $(\mathrm{p}<0.05)$ by Tukey test.

Elasticity and cohesiveness did not differ significantly among the formulations. Selani et al. (2016) evaluating hamburgers with the addition of by-products of pineapple and canola oil, also observed that the results for elasticity did differ between the formulations, with values ranging from 0.76 to 0.67 . The formulation H9 presented high value for the gumminess parameter, which is associated with its high fiber content. The insoluble fiber present in PPF can increase the consistency of meat products through the formation of a threedimensional network that is able to modify the rheological properties of the continuous phase of emulsions. According to Hautrive et al. (2008) the effects of fiber addition on meat texture differ according to the source of dietary fiber used, the amount added, the proportion of soluble and insoluble fibers, the hydrophilic and lipophilic nature of its constituents, $\mathrm{pH}$, fiber particle size and temperature of exposition during storage and cooking.

It can be observed in the sensory analysis results (Table 6) that all the formulations had similar scores for overall appearance and aroma $(p<0.05)$. The formulation H9 had the lowest value for flavor and texture, while the other samples showed similar values $(p>0.05)$. So, it can be inferred that the addition of up $6 \%$ of PPF did not negatively affect the sensory attributes of lamb burgers. Carvalho et al. (2019) reported that the addition of extracts of guarana seeds and pitanga leaves did not alter the acceptability of the lamb burgers, while Villalobos- 
Delgado (2015) observed that the addition of hop powder caused a slight decrease in the consumer acceptance of lamb burgers.

The values of the sensory parameters obtained in this work ranged from 5 and 8 (approximately), and based on the 9-point hedonic scale, they correspond to "not like and not dislike" to "like very much". The highest values of purchase intention were observed in the formulations control (H0) and with $3 \%$ or $6 \%$ of FPP addition, being the values close to 4 , that corresponds to "probably buy". It indicates that these products had chances of success in the consumer market. OLIVEIRA et al. (2021) also found similar scores, between 6 and 8 in the acceptance test, and between 3 and 4 for purchase intention, in lamb burger formulations with different levels of safflower seed in the feed diet.

\section{CONCLUSION}

The flour from peach palm by-product showed adequate nutritional and technological properties to be applied in the production of lamb burgers. The PPF addition positively affected the cooking properties of lamb burger formulations, without interfering in most of the color parameters. There was lower fat content and higher fiber content in the formulations with the PPF addition, especially when it was used at higher levels (6 and 9\%); however, its addition also caused a slight decrease in the protein content and an increase in hardness values. The microbiological parameters allowed the formulations to be analyzed as sensorial parameters. To achieve better sensorial acceptance levels up to $6 \%$ of PFF addition was recommended to lamb burgers production.

RESUMO: Há um interesse crescente pelo consumo de produtos à base de carne mais saudáveis e inovadores. O objetivo deste estudo foi produzir hambúrgueres de cordeiro, substituindo a gordura de porco por farinha de subproduto de palmito pupunha - FPP. Os hambúrgueres foram produzidos com a carne obtida de cordeiros que tiveram dieta suplementada com sementes de cártamo. A FPP foi adicionada nos níveis de $0 \%$ (H0), 3\% (H3), 6\% (H6) e 9\% (H9) em substituição à gordura. A farinha produzida com subproduto de palmito pupunha apresentou alto teor de fibras $(63,9 \%)$ e alta capacidade de absorção de água $\left(8,1 \mathrm{~g}\right.$. $\left.\mathrm{g}^{-1}\right)$ e absorção de óleo $\left(3,8 \mathrm{~g} \cdot \mathrm{g}^{-1}\right)$. A adição de FPP aumentou o rendimento após cocção $(68,2$ - 77,0\%), a retenção de umidade $(38,5-43,4 \%)$ e o teor de fibra alimentar $(3,2-7,0 \%)$ em relação a amostra H0, enquanto os parâmetros de cor foram semelhantes entre as formulações. Os atributos sensoriais aparência geral e aroma não diferiram ( $p>$ $0,05)$ entre os hamburgueres produzidos, mas, as maiores notas para sabor, textura e intenção de compra foram observadas para H0, H3 e H6. A adição de FPP aos hambúrgueres de cordeiro aumentou os valores de dureza e não afetou a elasticidade e a coesão. Os parâmetros microbianos mostraram que as formulações são seguras para consumo. Portanto, a FPP pode ser considerada uma alternativa de baixo custo para o enriquecimento nutricional de hambúrgueres de cordeiro, sendo o nível de $6 \%$ o mais recomendado devido à aceitação sensorial.

PALAVRAS-CHAVE: Bactris gasipaes. Fibra alimentar. Hambúrguer.

\section{REFERENCES}

ABREU, K. S. F.; VÉRAS, A. S. C.; FERREIRA, M. A.; MADRUGA, M. S.; MACIEL, M. I. S.; FÉLIX, S. C. R.; VASCO, A. C. C. M.; URBANO, S. A. Quality of meat from sheep fed diets containing spineless cactus (Nopalea cochenillifera Salm Dyck). Meat Science, Oxford, v. 148, p. 229-235, 2019. https://doi.org/10.1016/j.meatsci.2018.04.036

ANGOR, M. M.; AL-ABDULLAH, B. M. Attributes of low-fat beef burgers made from formulations aimed at enhancing product quality. Journal of Muscle Foods, Malden, v. 21, n. 2, p. 317-326, 2010.

https://doi.org/10.1111/j.1745-4573.2009.00184.x

APHA - American Public Health Association. Compendium of methods for the microbiological examination of foods. 4th ed. Washington: Amer Public Health Assn, 2001.

AZIZ, N. A. A.; HO, L. H.; AZAHARI, B.; BHAT, R.; CHENG, L. H.; IBRAHIM, M. N. M. Chemical and functional properties of the native banana (Musaacuminate $\mathrm{x}$ balbisiana Colla $\mathrm{cv}$. Awak) pseudo-stem and 
pseudo-stem tender core flours. Food Chemistry, Oxford, v. 128, n. 3, p. 748-753, 2011.

https://doi.org/10.1016/j.foodchem.2011.03.100

BARROS, J. C.; MUNEKATA, P. E. S.; PIRES, M. A.; RODRIGUES, I.; ANDALOUSSI, O. S.;

RODRIGUES, C. E. C.; TRINDADE, M. A. Omega-3- and fibre-enriched chicken nuggets by replacement of chicken skin with chia (Salvia hispanica L.) flour. LWT - Food Science and Technology, v. 90, p. 283-289, 2018. https://doi.org/10.1016/j.lwt.2017.12.041

BAUGREET, S.; KERRY, J. P.; BOTINESTEAN, C.; ALLEN, P.; HAMILL, R. M. Development of novel fortified beef patties with added functional protein ingredients for the elderly. Meat Science, Oxford, v. 122, p. 40-47, 2016. https://doi.org/10.1016/j.meatsci.2016.07.004

BOADA, L. D.; HENRÍQUEZ-HERNÁNDEZ, L. A.; LUZARDO, O. P. The impact of red and processed meat consumption on cancer and other health outcomes: Epidemiological evidences. Food and Chemical Toxicology, Oxford, v. 92, p. 236-244, 2016. https://doi.org/10.1016/j.fct.2016.04.008

BOLANHO, B. C.; DANESI, E. D. G.; BELÉIA, A. P. Characterization of flours made from peach palm (Bactris gasipaes Kunth) by-products as a new food ingredient. Journal of Food and Nutrition Research, Bratislava, v. 53, n. 1, p. 51-59, 2014

BOLANHO, B. C.; DANESI, E. D. G.; BELEIA, A. P. Peach palm (Bactris gasipaes Kunth) characterization and the potential of by-products flour processing. Food Science and Technology Research, Basel, v. 19, n. 6, p. 1061-1069, 2013. https://doi.org/10.3136/fstr.19.1061

BRAZIL. Normative Instruction $\mathrm{n}^{\circ} 20$, July, 31, 2000. Technical regulation of hamburger identity and quality. Official Gazette of the Federative Republic of do Brazil: section 1, Brasília, DF, p. 7, 2000.

BRAZIL. RDC $\mathrm{n}^{\mathrm{o}}$ 12, January, 02, 2001. Technical regulation on microbiological standards for food. Official Gazette of the Federative Republic of do Brazil: section 1, Brasília, DF, n. 7, p. 45-53, 2001.

BRAZIL. RDC n ${ }^{\circ} 54$, November, 12, 2012. Technical regulation on supplementary nutritional information. Official Gazette of the Federative Republic of do Brazil: section 1, Brasília, DF, p. 1-18, 2012.

CARVALHO, F. A. L.; LORENZO, J. M.; PATEIRO, M.; BERMÚDEZ, R.; PURRIÑOS, L.; TRINDADE, M. A. Effect of guarana (Paullinia cupana) seed and pitanga (Eugenia uniflora L.) leaf extracts on lamb burgers with fat replacement by chia oil emulsion during shelf life storage at $2{ }^{\circ} \mathrm{C}$. Food Research International, Amsterdam, v. 125, 2019. https://doi.org/10.1016/j.foodres.2019.108554

CHIKWANHA, O. C.; VAHMANI, P.; MUCHENJE, V.; DUGAN, M. E. R.; MAPIYE, C. Nutritional enhancement of sheep meat fatty acid profile for human health and wellbeing. Food Research International, Amsterdam, v. 104, p. 25-38, 2018. https://doi.org/10.1016/j.foodres.2017.05.005

COBELLIS, G.; ACUTI, G.; FORTE, C.; MENGHINI, L.; DE VINCENZIC, S.; ORRÙ, M.; VALIANI, A.; PACETTI, D.; TRABALZA-MARINUCCI, M. Use of Rosmarinus officinalis in sheep diet formulations: Effects on ruminal fermentation, microbial numbers and in situ degradability. Small Ruminant Research, Amsterdam, v. 126, p. 10-18, 2015. https://doi.org/10.1016/j.smallrumres.2015.01.018

DECKER, E. A.; PARK, Y. Healthier meat products as functional foods. Meat Science, Oxford, v. 86, n. 1, p. 49-55, 2010. https://doi.org/10.1016/j.meatsci.2010.04.021

DUTCOSKY, S. D. Sensory analysis of food. 4th ed. Curitiba: Champagnat, 2013.

ELLEUCH, M.; BEDIGIAN, D.; ROISEUX, O.; BESBES, S.; BLECKER, C. Dietary fiber and fiber-rich byproducts of food processing: Characterization, technological functionality and commercial applications: A 
review. Food Chemistry, Oxford, v. 124, n. 2, p. 411-421, 2011.

https://doi.org/10.1016/j.foodchem.2010.06.077

FAO - Food and Agriculture Organization of the United Nations. Live animals. Available from:

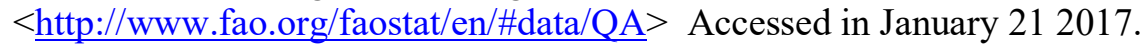

FLOREK, M.; LITWINCZUK, A.; SKATECKI, P.; TOPYTA, B. Influence of pH of fatteners' musculus longissimus lumborum on the changes of its quality. Polish Journal of Food and Nutrition Sciences, Poland, v. 13, n. 2, p. 195-198, 2004.

GUEDES-OLIVEIRA, J. M.; SALGADO, R. L.; COSTA-LIMA, B. R. C.; GUEDES-OLIVEIRA, J.; CONTEJUNIOR, C. A. Washed cashew apple fiber (Anacardium occidentale L.) as fat replacer in chicken patties.

LWT - Food Science and Technology, v. 71, p. 268-273, 2016. https://doi.org/10.1016/j.lwt.2016.04.005

HAUTRIVE, T. P.; OLIVEIRA, V. R.; SILVA, A. R. D.; TERRA, N. N.; CAMPAGNOL, P. C. B.

Physicochemical and sensorial analyses of ostrich hamburger. Food Science and Technology, Campinas, v.

28, p. 95-101, 2008. https://doi.org/10.1590/S0101-20612008000500016

HORWITZ, W.; LATIMER, G. Official methods of analysis of AOAC International. Gaithersburg: AOAC International, 2005.

HUANG, S. C.; TSAI, Y. F.; CHEN, C. M. Effects of wheat fiber, oat fiber, and inulin on sensory and physicochemical properties of Chinese-style sausages. Asian-Australasian Journal of Animal Sciences, Seoul, v. 24, n. 6 , p. $875-880,2011$. https://doi.org/10.5713/ajas.2011.10317

JITNGARMKUSOL, S.; HONGSUWANKUL, J.; TANANUWONG, K. Chemical compositions, functional properties, and microstructure of defatted macadamia flours. Food Chemistry, Oxford, v. 110, n. 1, p. 23-30, 2008. https://doi.org/10.1016/j.foodchem.2008.01.050

KIM, H. W.; MILLER, D. K.; LEE, Y. J.; KIM, Y. H. B. Effects of soy hull pectin and insoluble fiber on physicochemical and oxidative characteristics of fresh and frozen/thawed beef patties. Meat Science, Oxford, v. 117, p. 63-67, 2016. https://doi.org/10.1016/j.meatsci.2016.02.035

LEÃO, P. D.; FRANCA, A. S.; OLIVEIRA, L. S.; BASTOS, R.; COIMBRA, M. A. Physicochemical characterization, antioxidant capacity, total phenolic and proanthocyanidin content of flours prepared from pequi (Caryocar brasilense Camb.) fruit by-products. Food Chemistry, Oxford, v. 225, p. 146-153, 2017. https://doi.org/10.1016/j.foodchem.2017.01.027

LÓPEZ-LÓPEZ, I.; COFRADES, S.; YAKAN, A.; SOLAS, M. T.; JIMÉNEZ-COLMENERO, F. Frozen storage characteristics of low-salt and low-fat beef patties as affected by Wakame addition and replacing pork backfat with olive oil-in-water emulsion. Food Research International, Amsterdam, v. 43, n. 5, p. 1244-1254, 2010. https://doi.org/10.1016/j.foodres.2010.03.005

LU, F.; LIU, Y.; LI, B. Okara dietary fiber and hypoglycemic effect of okara foods. Bioactive Carbohydrates and Dietary Fibre, Amsterdam, v. 2, n. 2, p. 126-132, 2013. https://doi.org/10.1016/j.bcdf.2013.10.002

NASSU, R. T.; UTTARO, B.; AALHUS, J. L.; ZAWADSKI, S.; JUÁREZ, M.; DUGAN, M. E. R. Type of packaging affects the colour stability of vitamin E enriched beef. Food Chemistry, Oxford, v. 135, n. 3, p. 1868-1872, 2012. https://doi.org/10.1016/j.foodchem.2012.06.055

NCR - National Research Council. Nutrient requirement of small ruminants: sheep, goats, cervids, and new world camelids. 1th ed. Washington: National Academy Press, 2007.

OLIVEIRA, M. R. C.; ECHEVERRIA, L.; MARTINEZ, A. C.; GOES, R. H. T. B.; SCANAVACCA, J.; BARROS, B. C. B. Safflower seed supplementation in lamb feed: effects upon fatty acid profile and quality of 
meat patty formulations. Annals of the Brazilian Academy of Sciences, Rio de Janeiro, v. 93, n. 3, p. 1-11, 2021. https://doi.org/10.1590/0001-3765202120190903

PETRACCI, M.; BIANCHI, M.; MUDALAL, S.; CAVANI, C. Functional ingredients for poultry meat Products. Trends in Food Science \& Technology, London, v. 33, n. 1, p. 27- 39, 2013. https://doi.org/10.1016/j.tifs.2013.06.004

PIÑERO, M. P.; PARRA, K.; HUERTA-LEIDENZ, N.; ARENAS DE MORENO, L.; FERRER, M.; ARAUJO, S.; BARBOZA, Y. Effect of oat's soluble fibre (b-glucan) as a fat replacer on physical, chemical, microbiological and sensory properties of low-fat beef patties. Meat Science, Oxford, v. 80, n. 3, p. 675-680, 2008. https://doi.org/10.1016/j.meatsci.2008.03.006

POLIZER, Y. J.; POMPEU, D.; HIRANO, M. H.; FREIRE, M. T. A.; TRINDADE, M. A. Development and evaluation of chicken nuggets with partial replacement of meat and fat by pea fibre. Brazilian Journal of Food Technology, Campinas, v. 18, n. 1, p. 62-69, 2015. https://doi.org/10.1590/1981-6723.4914

PSZCZOLA, D. E. Fiber's new visibility. Food Technology, Chicago, v. 62, n. 12, p. 61-71, 2008.

RESENDE, L. M.; FRANCA, A. S.; OLIVEIRA, L. S. Buriti (Mauritia flexuosa L. f.) fruit by-products flours: Evaluation as source of dietary fibers and natural antioxidants. Food Chemistry, Oxford, v. 270, p. 53-60, 2019. https://doi.org/10.1016/j.foodchem.2018.07.079

SEABRA, L. M. J.; ZAPATA, J. F. F.; NOGUEIRA, C. M. Cassava starch and oatmeal as fat replacers of lamb burgers. Food Science and Technology, Campinas, v. 22, n. 3, p. 244-248, 2002.

https://doi.org/10.1590/S0101-20612002000300008

SELANI, M. M.; SHIRADO, A. N.; MARGIOTTA, G. B.; SALDAÑA, E.; SPADA, F. P.; PIEDADE, S. M. S.; CONTRERAS-CASTILLO, C. J.; CANNIATTI-BRAZACA, S. G. Effects of pineapple by product and canola oil as fat replacer son physicochemical and sensory quality of low-fat beef burger. Meat Science, Oxoford, v. 112, n. 1, p. 69-76, 2016. https://doi.org/10.1016/j.meatsci.2015.10.020

SREERAMA, Y. N.; SASHIKALA, V. B.; PRATAPE, V. M.; SINGH, V. Nutrients and antinutrients in cowpea and horse gram flours in comparison to chickpea flour: Evaluation of their flour functionality. Food Chemistry, Oxford, v. 131, n. 2, p. 462-468, 2012. https://doi.org/10.1016/j.foodchem.2011.09.008

TREVISAN, Y. C.; BIS, C. V.; HENCK, J. M.; BARRETTO, A. C. S. Effect of the addition of oat fiber on the physicochemical properties of cooked frozen hamburger with reduced fat and salt. Brazilian Journal of Food Technology, Campinas, v. 19, p. 1-8, 2016. https://doi.org/10.1590/1981-6723.7915

VELIOGLU, H. M.; VELIOGLU, S. D.; BOYACI, I. H.; YILMAZ, I.; KURULTAY, S. Investigating the effects of ingredient levels on physical quality properties of cooked hamburger patties using response surface methodology and image processing technology. Meat Science, Oxford, v. 84, n. 3, p. 477-483, 2010.

https://doi.org/10.1016/j.meatsci.2009.10.001

VILLALOBOS-DELGADO, L. H.; CARO, I.; BLANCO, C.; BODAS, R.; ANDRÉS, S.; GIRÁLDEZ, F. J.; MATEO, J. Effect of the addition of hop (infusion or powder) on the oxidative stability of lean lamb patties during storage. Small Ruminant Research, Amsterdam, v. 125, p. 73-80, 2015.

https://doi.org/10.1016/j.smallrumres.2015.02.008

WANG, J.; SUO, G.; WIT, M.; BOOM, R. M.; SCHUTYSER, M. A. I. Dietary fibre enrichment from defatted rice bran by dry fractionation. Journal of Food Engineering, Oxford, v. 186, p. 50-57, 2016.

https://doi.org/10.1016/j.jfoodeng.2016.04.012

WATKINS, P. J.; KEARNEY, G.; ROSE, G.; ALLEN, D.; BALL, A. J.; PETHICK, D. W.; WARNER, R. D. Effect of branched-chain fatty acids, 3-methylindole and 4-methylphenol on consumer sensory scores of grilled lamb meat. Meat Science, Oxford, v. 96, n. 2, p. 1088-1094, 2014. https://doi.org/10.1016/j.meatsci.2012.08.011 